\title{
Overcoming Refugee Containment and Crisis
}

\author{
Cathryn Costello*
}

Imagine a system in which you had to break the law and risk your life in order to enjoy its key right, a right to live lawfully in a political and legal community. That is the open secret at the heart of the so-called "Common European Asylum System" ("CEAS"). The EU and its Member States systematically erect barriers for those who would enter to claim asylum, forming part of the system of the containment of refugees in the Global South. Refugee containment is not only a European practice, but many of the policies and practices that are central to refugee containment are of fairly recent European origin. This Article identifies the costs of this refugee containment, not only for refugees and asylum-seekers, but also for Europe itself, its politics, and its adherence to the rule of law in particular. Containment contributed to the events styled as the 2015 refugee crisis in Europe, yet the crisis has generated a more intensified set of containment practices, also likely to backfire.

Two clarifications at the outset:

First, in focusing on containment, I could be accused of ignoring the positive, protective aspects of European asylum policies. Indeed, there have been some remarkably inclusive developments in Europe in the past years, such as the fairly high converging recognition rates for certain nationalities seeking protection, including those fleeing conflict. This Article, however, starts from the premise that refugee containment undermines any overall positive assessment of Europe's treatment of refugees.

Second, by focusing on illegalized refugees, I do not wish to suggest that most migration is illegal. Quite the contrary: Most migration is legal, by a large measure, and some asylum-seekers do manage to travel legally to claim asylum in Europe-those from the Western Balkans, for instance, and Venezuelans currently. Notably, in both cases their asylum claims are usually rejected, although most Venezuelans are currently allowed to stay under ad hoc national humanitarian permits. In contrast to many other travelers, however, those likely to seek asylum and get it are generally unlikely to be able to do so legally. Europe's highly stratified admissions policies consistently exclude would-be asylum-seekers.

This Article first sets out the costs of containment, and second suggests how Europe might overcome the containment-induced crisis and work to dismantle at least some aspects of containment.

\section{A. The Costs of Containment}

\section{The Human Costs of Containment}

It has long been recognized that some refugees may have to break immigration laws in order to seek asylum. The drafters of the 1951 United Nations Convention Relating to the Status of

${ }^{\star}$ Andrew W. Mellon Professor in Refugee and Migration Law at the Refugee Studies Centre, University of Oxford. The author is currently the PI on an ERC Starter Grant RefMig, Grant Agreement 716968. 
Refugees acknowledged as much in including a provision to protect refugees from penalization for their unlawful entry and stay. ${ }^{1}$ Nowadays, however, civil carrier sanctions and the criminalization of an overbroad conception of smuggling mean that those without their papers in order cannot board the thousands of cheap safe flights and ferries that bring other passengers to Europe daily. ${ }^{2}$ EU Member States could make asylum and other legal routes of access more readily accessible without dangerous journeys, but the opposite trend is apparent-as the demand for refuge grows, access to asylum contracts and the demand for the services of smugglers grows.

Containment evidently has an immense cost in human lives. Those highly likely to be recognized as refugees in Europe are precisely those least likely to have legal means to get it. Take Eritrean refugees, for example: Eritreans flee a repressive regime, and their claims to asylum are generally recognized. It is now over six years since the October 2013 shipwreck of a boat carrying mainly Eritreans in which hundreds drowned. Although this event did seem to shock the conscience, in hindsight it prompted only a brief Italian operational response, and since then, deaths at sea have increased as a proportion of irregular arrivals using this maritime route. Within the Eritrean diaspora, the anniversary is moment to share public grief. It is a painful reminder of the unenviable choices facing a generation who face either oppressive conscription at home, precarious exile often in dire conditions in a neighboring country, or the dangerous journey to Europe. For other refugee diasporas, the dangerous journey to Europe has developed its own idiom. For Somalis, a specific term, going Tahriib, refers to facing the risks of protracted irregular journeys. Alternatively, bufus is the malaise of languishing in a camp, with few opportunities except the extremely rare and dwindling prospect of resettlement. The human costs of containment are not only deaths and injuries suffered on the move, but also debt burdens, exploitation risks, separated families, and disrupted communities.

Moreover, the human costs of refugee containment are not only meted out at a distance. The EU now supports a network of places of detention and containment at the EU's periphery in order to prevent would-be refugees from seeking asylum beyond. On any given day, the brutal manifestations of containment both outside and within the EU are all too evident. The head of the EU Fundamental Rights Agency, Michael O'Flaherty, recently described the EU hotspot in Moria, Greece, as "the single most worrying fundamental rights issue that we are confronting anywhere in the European Union." 3 The "hotspot" approach is one of the EU responses to the refugee arrivals of 2015. On November 21, 2019, the Greek government announced it would close some of the island camps, but it plans to move asylum-seekers into detention camps. Detaining en masse is a violation of EU, human rights, and refugee law, and the history of detention conditions in Greece suggests that human and degrading conditions tend to prevail.

\section{The Political Costs of Containment}

Illegalized asylum-seeking is deeply hypocritical, evidently. There are political costs to the lack of integrity in such a position, for sure. This Section turns to another stark political cost, namely that containment fails as a policy in that it does not actually contain. When it fails, it may do so spectacularly. ${ }^{4}$

\footnotetext{
${ }^{1}$ United Nations Convention Relating to the Status of Refugees art. 31, July 28, 1951, 189 U.N.T.S. 137. See also Cathryn Costello et al., Article 31 of the 1951 Convention Relating to the Status of Refugees, UNHCR (July 2017), http://www.refworld. org/docid/59ad55c24.html.

${ }^{2}$ Jennifer Allsopp \& Cathryn Costello, Smuggling Prohibitions vs. Duties of Humanity, Rethinking Refuge (Jun. 20, 2019), https://www.rethinkingrefuge.org/articles/smuggling-prohibitions-vs.-duties-of-humanity.

${ }^{3}$ Nikolaj Nielsen, Greek Migrant Hotspot Now EU's “Worst Rights Issue”, EUObserver (Nov. 2, 2019), https://euobserver. com/migration/146541.

${ }^{4}$ See also Hemme Battjes et al., The Crisis of European Refugee Law: Lessons from Lake Success, SSRN 1, 30 (May 23, 2016), https://papers.ssrn.com/sol3/papers.cfm?abstract_id=2783247.
} 
This is what happened in Europe in 2015, with one million people making dangerous journeys to Europe, with an estimated 3,770 deaths at sea. ${ }^{5}$ Most traveled from Turkey to the Greek islands on unstable rubber dinghies and onward to Northern Europe to claim asylum. Bear in mind that Turkey has two land borders with the EU, both of which are fortified and the sites of documented border violence and deaths. When land borders are sealed, and regular means of cheap and safe travel legally blocked, refugees turn to other means of flight, particularly if they have the material means to do so.

Although 2015 was by no means only about Syrian displacement, without the Syrian conflict, the tipping point into something extraordinary seems unlikely. And that conflict began four years earlier. Displacement has been a tool throughout the Syrian conflict, with most of the population displaced multiple times within the borders of the country. Of those who fled outside of Syria, most remain in Turkey, Lebanon, and Jordan. ${ }^{6}$ Europe had several years to address the potential of that Syrians would seek protection in Europe, and it effectively chose to hope that containment would work. The cost of doing nothing was to create demand for smugglers, and a political opportunity in particular for Turkey, keen to leverage refugees to its political advantage. It is unclear whether there was Turkish state complicity in the refugee exodus, but the Turkish state has evidently exploited the aftermath.

When the EU sought to control the refugee arrivals in 2016, it turned to extra-legal means, which so far have withstood legal challenge. The EU-Turkey deal entails additional aid to Turkey to support Syrian refugees and promises to examine Turkish nationals' visa-free access to the EU and reinvigorate the accession process. To contain the flow, they agreed to return refugees who arrived on the Greek islands to Turkey swiftly. Empirically, the impact of the EU-Turkey deal is disputed. There is little evidence to support the official claim that it restored control over admissions and good reason to support that the large influx was waning already.

The EU-Turkey deal has also distorted the political relationship between the EU and Turkey at a time when outside pressure against the seemingly inexorable slide towards authoritarianism is more needed than ever. Turkey's military incursion into Northern Syria, with all the human rights violations and atrocities it seems depressingly likely to entail, naturally prompted some fairlymuted criticism. ${ }^{8}$ In response, Erdogan's impunity is all too evident: "Hey EU, wake up. I say it again: if you try to frame our operation there as an invasion, our task is simple: we will open the doors and send 3.6 million migrants to you."

Many scholars have problematized the distortive effective of migration control on other agendas. ${ }^{10}$ Ruben Andersson and David Keen have written of the dangers of self-perpetuating "war on immigration," drawing persuasive analogies with the "war on terror" and "war on drugs." 11 There is increasing evidence of clear adverse impact on the ground, on human rights, and on efforts to foster good governance-especially across Africa. In particular, EU pressure to suppress mobility

\footnotetext{
${ }^{5}$ Over 3,770 Migrants Have Died Trying to Cross the Mediterranean to Europe in 2015, Missing MigRANTS PROJECT (Dec. 31, 2015), http://missingmigrants.iom.int/over-3770-migrants-have-died-trying-cross-mediterranean-europe-2015.

${ }^{6}$ Out of 5,718,489 Syrians who fled, around 3.7 million (65.5\%) remain in Turkey; 918,974 (16.1\%) remain in Lebanon; 654,266 (11.4\%) remain in Jordan; 234,831 (4.1\%) remain in Iraq; and 129,779 (2.3\%) remain in Egypt. Syria Regional Refugee Response, UNHCR (Nov. 7, 2019), https://data2.unhcr.org/en/situations/syria.

${ }^{7}$ Battjes et al., supra note 4, at 15.

${ }^{8}$ Claus Kreß, A Collective Failure to Prevent Turkey's Operation "Peace Spring” and NATO's Silence on International Law, EJIL: TALK! (Oct. 14, 2019), https://www.ejiltalk.org/a-collective-failure-to-prevent-turkeys-operation-peace-spring-andnatos-silence-on-international-law/.

${ }^{9}$ Nikolaj Nielsen, Erdogan: Refugees Will Enter Europe Unless EU Does More, EUObSERver (Nov. 8, 2019), https:// euobserver.com/migration/146566.

${ }^{10}$ See, e.g., Kelly Greenhill, Weapons of Mass Migration: Forced Displacement, Coercion, and Foreign Policy (2010).

${ }^{11}$ David Keen \& Ruben Andersson, Double Games: Success, Failure and the Relocation of Risk in Fighting Terror, Drugs and Migration, 67 Pol. GEOGRAPHY 100, 102 (2018).
} 
and fight smuggling ends up often supporting oppressive policing, frequently cutting across regional commitments to liberalize movement. At their worst, EU funds and practices are supporting despots and perpetrators of atrocities ${ }^{12}$ and creating state-based protection rackets for smuggling. ${ }^{13}$

The response to the European refugee crisis has been politically costly in a wider sense, with reverberations beyond the treatment of refugees. Due to containment practices, refugee arrivals are unpredictable and invariably look like a crisis. Within Europe, the political costs have been increased polarization and a rise of right-wing populism. Irregular refugee arrivals are chaotic, unpredictable, and ripe to be exploited by fear-mongering politicians. What is really a crisis for refugees becomes a crisis for Europe. As Cas Mudde has explained:

[F]raming of a spike in asylum-seekers as a "refugee crisis," together with rhetoric linking this "crisis" to terrorism, created a "perfect storm" for the populist radical right. It brought their key issues-immigration, security, and Euroskepticism - to the top of the agenda, and it made voters more receptive to nativist, authoritarian, and populist appeals. ${ }^{14}$

It remains to be seen whether this new normal really blocks legal reforms. Although we often assume refugee issues tend to polarize, there is sound evidence to support the view that European public opinion generally supports refugee protection once it has some limits, ${ }^{15}$ in particular if it is in fair shares. ${ }^{16}$

\section{Rule of Law Costs of Containment}

Although law is the tool to suppress refugee mobility, many containment practices are themselves an affront to legality. For example, we are currently witnessing the normalization of practices that entail human rights violations, such as routine immigration detention. ${ }^{17}$ There are other rule of law costs of containment. This Section focuses on the EU-Turkey deal and the related practices in Greece as just one visible manifestation of how legality is undermined by containment.

Legally, the deal depends on the assessment of Turkey as a safe country for refugees. The preponderance of expert legal opinion, however, is that Turkey is not a "Safe Third Country" under the current legislative framework in EU law, and it also may not meet the threshold for safe returns under human rights law. ${ }^{18}$ Initially, the Greek Asylum Appeals Committees followed the orthodox legal view and refused to permit refugee returns to Turkey. In an EU rightly preoccupied with rule of law crises, the EU response was extraordinary: It put immense pressure on Greece to alter the composition of these appeals bodies, in effect to lead them to come to a different legal assessment.

\footnotetext{
${ }^{12}$ Ruben Andersson \& David Keen, The West's Obsession with Border Security Is Breeding Instability, ForeIGN POL'Y (Nov. 16, 2019), https://foreignpolicy.com/2019/11/16/border-security-european-union-instability-illegal-immigration/.

${ }^{13}$ See generally Luca Raineri, Human Smuggling Across Niger: State-Sponsored Protection Rackets and Contradictory Security Imperatives, 56 J. MOD. AFr. STUD. 63 (2018).

${ }^{14}$ See generally Cas Mudde, The 2019 EU Elections: Moving the Center, 30 J. Democracy 20 (2019).

${ }^{15}$ Anne-Marie Jeannet et al., What Asylum and Refugee Policies Do Europeans Want?: Evidence From a Cross-National Conjoint Experiment, CADMUS EUI RESEARCH Repository (Oct. 2019), http://hdl.handle.net/1814/64384.

${ }^{16}$ Kirk Bansak et al., Aristotelian Equality and International Cooperation: Europeans Prefer a Proportional Asylum Regime (Stanford Zurich Immigration Policy Lab Working Paper No. 16-02, 2016), https://fsi.stanford.edu/publication/aristotelianequality-and-international-cooperation-europeans-prefer-proportional-asylum.

${ }^{17}$ See generally Cathryn Costello \& Minos Mouzourakis, EU Law and the Detainability of Asylum-Seekers, 35 REFUGEE SuRV. Q. 47 (2016).

${ }^{18}$ Steve Peers and Emanuela Roman, The EU, Turkey and the Refugee Crisis: What could possibly go wrong? EULAW ANALYSIS http://eulawanalysis.blogspot.com/2016/02/the-eu-turkey-and-refugee-crisis-what.html Cf. Daniel Thym, Why the EU-Turkey Deal is Legal and a Step in the Right Direction, Verfassungsblog (Mar. 11, 2016), http://eumigrationlawblog.eu/why-theeu-turkey-deal-can-be-legal-and-a-step-in-the-right-direction/.
} 
Greece has since reformed the bodies' composition twice, diluting the independence of the bodies and removing the members with a human rights and UNHCR affiliation. ${ }^{19}$

Meanwhile, at the EU level, the EU Courts deemed a challenge to the EU-Turkey deal inadmissible, declaring it not to be an EU act notwithstanding its profound legal effects and apparent authorship. ${ }^{20}$ And later, in a 13-12 ruling in September 2017, the Greek Council of State decided that Turkey was after all an STC, and that this legal question did not warrant a reference to the CJEU. ${ }^{21}$ The Greek higher courts have not been entirely supine in the face of the political pressures, however. The Greek Council of State also ruled that there was no legal basis for keeping refugees and asylum-seekers on the Greek islands, but the government continues to defy that ruling. $^{22}$

\section{B. Overcoming Crisis}

Thus far, EU responses to the refugee crisis have largely been more of the same-more containment, more restriction. Indeed, the prevailing crisis narrative obscures the deeper causes of refugee arrivals in Europe. So rather than a recognition that "containment backfired," we have "Merkel invited a million refugees" and even the now widespread mythos of her breach of the Rechstaat in so doing. ${ }^{23}$ Hilary Charlesworth's writings on crises reminds us that such distortion is typical of crisis narratives. ${ }^{24}$ Although crises may sometimes serve as a catalyst for deep change, prompting a "never again" impulse, equally they can distract from structural problems or even generate policy paralysis. ${ }^{25}$ Regrettably, policy paralysis is precisely what is currently evident in the EU. ${ }^{26}$

One of the most depressing aspects of the policy discussion on legalizing access to asylum is the policy paralysis. Policy makers frequently claim that any moves to legalize access to asylum would just create more applications on top of the irregular arrivals. This claim rarely draws on any empirical evidence. We do know that the opposite holds - the best available evidence illustrates that restriction drives would-be migrants and asylum-seekers in particular into irregularity. ${ }^{27}$ Smaller studies, and indeed much personal testimony, support the contention that refugees often try to flee legally and only turn to irregular means once there are no other options available. The narrative of Alan Kurdi's well-documented attempts to join family in Canada briefly politicized the issue of refugee admissions there. The notion that offering legal routes to travel-which by definition are cheaper, safer, faster, and legal —would not diminish demand for the services of smugglers — rests on a series of implausible hypotheses.

\footnotetext{
${ }^{19}$ Mariana Gkliati, The EU-Turkey Deal and the Safe Third Country Concept Before Greek Asylum Appeals Committees, 3 J. For Critical Migration \& Border Regime Stud. 213, 217-219 (2017).

${ }^{20}$ Joined Cases C-208 \& C-210/17 P, NF et al. v. European Council, ECLI:EU:C:2018:705, Judgment of 12 Sept. 2019.

${ }^{21}$ Symboulion Epikrateias [S.E.] [Supreme Administrative Court] 2346 \& 2348/2017 (Greece). See Angeliki Tsiliou, When Greek Judges Decide Whether Turkey Is a Safe Third Country Without Caring Too Much for EU Law, EU IMMIGR. \& AsYLUM L. \& POL'Y (May 29, 2018), https://eumigrationlawblog.eu/when-greek-judges-decide-whether-turkey-is-a-safe-third-countrywithout-caring-too-much-for-eu-law/.

${ }^{22}$ Greece: Government Defies Court on Asylum Seekers, Hum. RTs. WATCH (Apr. 25, 2018), https://www.hrw.org/news/ 2018/04/25/greece-government-defies-court-asylum-seekers.

${ }^{23}$ Stephan Detjen \& Maximilian Steinbeis, Die Zauberlehrlinge: Der Streitumdie Flüchtlingspolitik und der Mythos vom RechtsBruch (2019).

${ }^{24}$ See generally Hilary Charlesworth, International Law: A Discipline of Crisis, 65 MoD. L. REv. 377 (2002).

${ }^{25}$ Benjamin Authers \& Hilary Charlesworth, The Crisis and the Quotidian in International Human Rights Law, 44 NETH. Y.B. INT'L L. 19, 22 (2014).

${ }^{26}$ See generally Sandra Lavenex, "Failing Forwards" Towards Which Europe? Organized Hypocrisy in the Common European Asylum System, 56 J. Common Mкт. STUd. 1195 (2018); Virginie Guiraudon, The 2015 Refugee Crisis Was Not a Turning Point: Explaining Policy Inertia in EU border Control, 17 Eur. Pol. SCI. 151 (2018); Arne Niemann \& Natascha Zaun, EU Refugee Policies and Politics in Times of Crisis: Theoretical and Empirical Perspectives, 56 J. COMMON MKT. STUD. 3 (2018).

${ }^{27}$ Hein de Haas et al., International Migration: Trends, Determinants, and Policy Effects, Population \& Dev. Rev. (Oct. 8, 2019), https://onlinelibrary.wiley.com/doi/epdf/10.1111/padr.12291.
} 
There are many ways to legalize mobility - after all, most mobility is legal. We don't need to design special processes for refugees, but rather we need to let refugees benefit from the opportunities for transnational mobility currently offered to others. Another important focus is on the role of private actors, both carriers and rescuers. It is the privatization of border controls that renders irregular flight deadly, and creates civil carrier sanctions, in particular, that need greater focus and attention, both legal and ethical. ${ }^{28}$

So how do we move from perpetual crisis to a crisis as catalyst for change? One powerful discursive tool is to think in terms of atrocity rather than crisis. There is no particular agent implied in the term crisis; the term does not tell us who did what or who is responsible. Thinking about deaths at sea, dangerous journeys, and the comprehensive illegalization of refugee travel as an atrocity is not an obvious move, but is increasingly, plausible and ethical, and indeed, legal arguments have emerged to that effect. ${ }^{29}$ While they may provoke resistance, they are crucial to reveal the deliberate policies and practices that underpin the global regime of refugee containment. Sikkink has identified some of the potential of international criminal justice to bolster human rights protections by ending impunity for perpetrators of mass atrocities. ${ }^{30}$ In contemporary Europe, we are witnessing a distortion of the proper role of the criminal law-an overbroad criminalization of irregular migration itself and indeed, all forms of assistance, even life-saving assistance, to those cast as irregular migrants. We need to turn the gaze back to the creators of the practices of containment and seek new ways to ensure we understand the harms these practices inflict.

Beyond invoking the expressive power of holding to account, there are many small changes that could be made to ensure that refugee mobility is treated as part of refugee protection, not its antithesis. While there are no panaceas, and it is unlikely that refugee containment will be dismantled in toto, its impacts can be mitigated, and lawyers and legal scholars have an important role to play here. Admittedly, thus far, attempts to legalize access to asylum by litigation have also failed. The Court of Justice of the European Union ("CJEU”) ruled against any duty to consider fundamental rights in visa processing in a case tailor-made for legal innovation. ${ }^{31}$ Currently pending before the Grand Chamber of European Court of Human Rights ("ECtHR") is a case concerning consular obligations to consider human rights when assessing whether to issue visas. The outcome is not clear, but there is reason to hope that some legal advances may be made to increase legal access to asylum.

Without a rethink, the CEAS is destined to remain a policy failure, an ethical sore, and political tinderbox. In order to rethink, we must disrupt the settled crisis narrative from 2015, deal with the systematic failings of containment, and find workable alternatives.

\footnotetext{
${ }^{28}$ Theodore Baird \& Thomas Spijkerboer, Carrier Sanctions and the Conflicting Legal Obligations of Carriers: Addressing Human Rights Leakage, 11 Amsterdam L. REV. 4 (2019).

${ }^{29} \mathrm{~A}$ number of scholarly and activist interventions have sought to argue that the EU and its Member States have perpetrated crimes against humanity and other international crimes in their approaches to migration control. These interventions are assessed in a forthcoming Special Issue of the German Law Journal, currently being edited by Cathryn Costello and Itamar Mann.

${ }^{30}$ Kathryn Sikkink, The Justice Cascade: How Human Rights Prosecutions Are Changing World Politics (2011).

${ }^{31}$ ECJ, Case C-638/16, X \& X v. État Belge, ECLI:EU:C:2017:173, Judgment of 7 Mar. 2017.
}

Cite this article: Costello C (2020). Overcoming Refugee Containment and Crisis. German Law Journal 21, 17-22. https:// doi.org/10.1017/glj.2019.89 